\title{
Spider checklist for the Blouberg, in the Vhembe Biosphere Reserve, South Africa
}

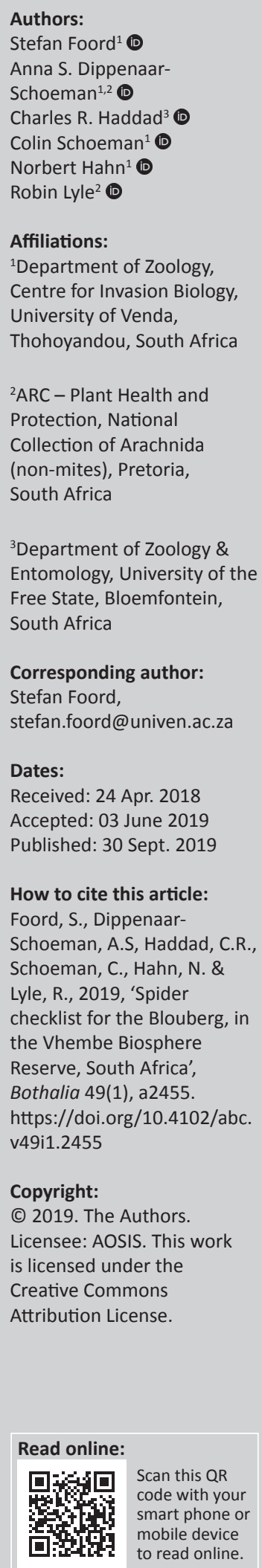

Background: The north-eastern mountainous region of South Africa has been identified as a spider diversity hotspot and centre of endemisim. The Blouberg is an isolated inselberg that forms part of the Soutpansberg geological complex, the northernmost mountain in South Africa.

Objectives: This article provides an updated species list of the Blouberg spiders, which includes details of the distribution patterns and conservation statuses of all taxa. Exotic species and species of special conservation concern are identified.

Method: Surveys were conducted between 2005 and 2012, and a range of collecting methods were used to sample both the ground and field layers.

Results: A total of 47 families were sampled in 210 genera and 346 species. The families of Salticidae (45 spp.), Gnaphosidae (32 spp.), Thomisidae (31 spp.), Araneidae (26 spp.) and Lycosidae (24 spp.) were the most diverse. Five species are of conservation concern, one species is Vulnerable, one is possibly exotic and 62 species are South African endemics.

Conclusion: Presently, 17\% of South African species are protected on the mountain and its surrounding foothills. The latter are of particular conservation concern, while the mountaintop and its associated habitats are under-sampled.

Keywords: South African Survey of Arachnida; conservation status; endemicity; exotic species; threats; Limpopo province.

\section{Introduction}

The Blouberg (BB) is an inselberg that is geologically related, but geomorphically distinct from Soutpansberg (SPB), separated from it by a plain of approximately $15 \mathrm{~km}$ (Hahn 2011). The spiders of the SPB are relatively well known and very diverse, with $>600$ species and 13 endemic taxa (Foord, Dippenaar-Schoeman \& Stam 2013). Although 30 times smaller than the SPB, the BB is $300 \mathrm{~m}$ higher (Hahn 2011). Previous surveys of the mountain were restricted to the Blouberg Nature Reserve on the north-eastern foothills of the mountain (Muelelwa et al. 2010), while the mountain massif itself has been neglected with no known records.

Within the ambit of the South African National Survey of Arachnida (SANSA) (DippenaarSchoeman et al. 2015), the current study presents the sampling in the BB, listing the global distribution, endemicity and conservation profile for each species.

\section{Method}

\section{Study area}

The BB is an inselberg of the same geological formation as the SPB, but separated from it by $15 \mathrm{~km}$ gap of relatively flat plains (Figure 1). Blaauwberg at $2051 \mathrm{~m}$ above sea level is the highest peak on the Blouberg, protruding $1200 \mathrm{~m}$ from the surrounding plain. The mountain predominantly consists of erosion-resistant quartzite and quartzitic sandstones, the sandy soils derived from these formations are acidic, well drained and nutrient poor (Mostert et al. 2008). Aeolian Kalahari sands form fine-grained deep soils on the northern plains, while clayey well-drained soils derived from diabase and basalt intrusions characterise the southern slopes. It is a summer rainfall area, with cold and dry early winters, hot and dry late winter and early spring conditions developing into hot and wet summers.

The southern mountain slopes consist of mixed bushveld becoming forest at increased elevations. The habitat of the upper plateau situated at an altitude of about $1600 \mathrm{~m}$ is mostly of mixed 


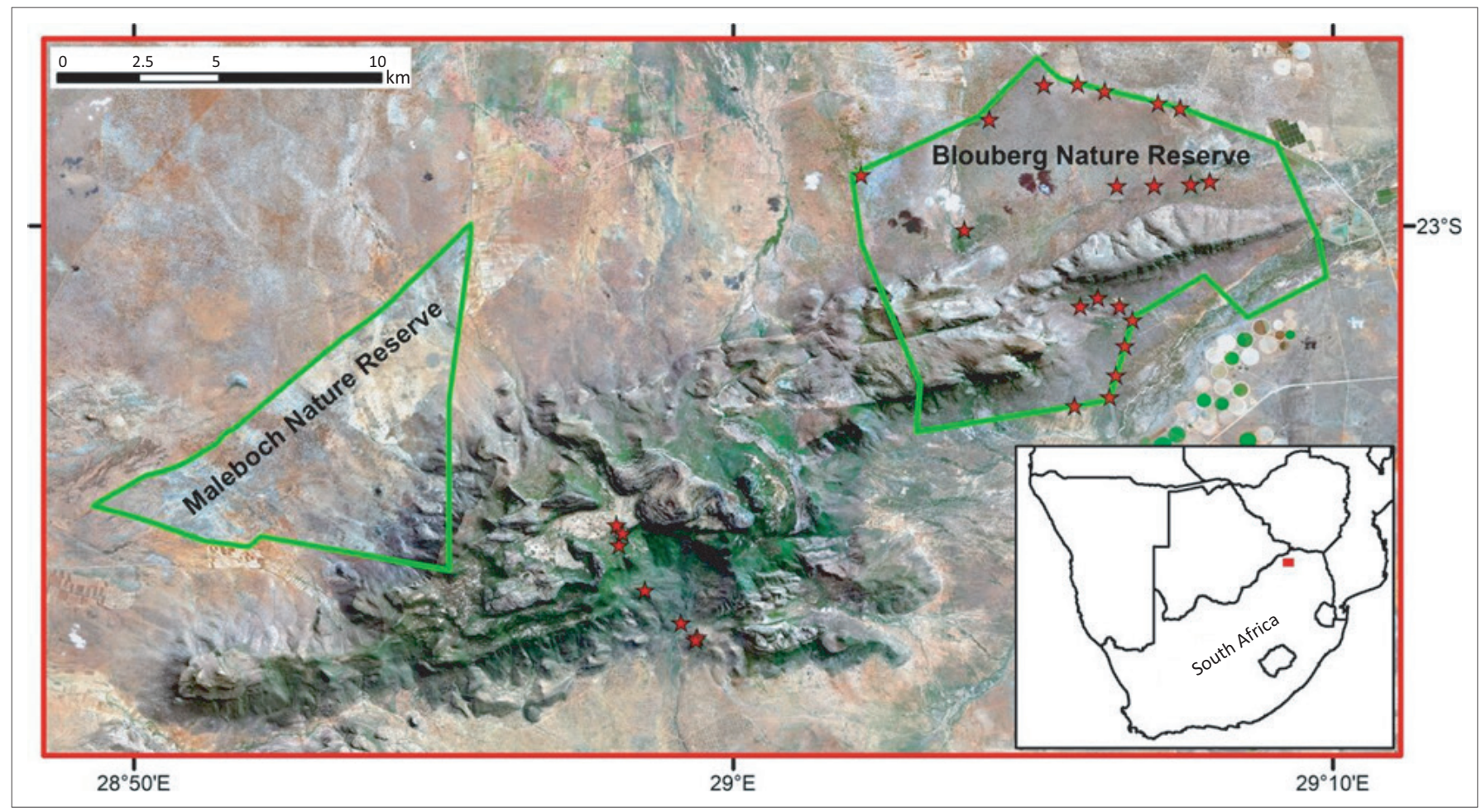

FIGURE 1: Map of study area. Symbols (stars) indicate sampling localities.

grassland with wooded patches and bushland limited to drainage lines that are directed upwards to the summit (Figure 2a-c). Foothills include Kalahari sandveld on the northern aspect to sweet bushveld to the east and west (Figure 2d-g). Habitats also include tamboti woodland, fig tree forests, baobabs forests and floodplains (Figure 2).

\section{Sampling methods and period}

Spiders were sampled within the context of focused research projects between 2005 and 2006 (Muelelwa et al. 2010), 2012 (Schoeman et al. in press) and as part of a SANSA (DippenaarSchoeman et al. 2015) survey of the mountain in 2009 (Figure 1). Sampling consisted of pitfall traps, litter sifting, sweeping, beating and hand collecting.

Species were identified by the first three authors. Voucher specimens are deposited in the National Collection of Arachnida (Agricultural Research Institute - Plant Health \& Protection, Pretoria). Agelenidae, Araneidae, Dictynidae and Theridiidae taxonomy are in need of major revisions, and many specimens in these families are unidentified (Appendix 1). We only list generic names for immature specimens.

\section{Distribution value}

The distribution values (DVs) are provided for each species (Table 1) calculated based on current known global distribution, which included six distribution categories, ranging from:

$6=$ Blouberg endemic (BBE), known only from type/one locality only; 5 = South African endemic known from the Limpopo province (SAE-LE), wider than type locality; $4=$ South African endemic known from two adjoining provinces; 3 = South African endemics > two provinces or two provinces not adjoining; $2=$ Southern Africa Endemics (STHE) (south of Zambezi and Kunene Rivers); 1 = Afrotropical Region Endemics (AE); $0=$ Africa and beyond (C).

\section{Conservation profiles}

Species known from immatures only, or undetermined taxa, were Not Evaluated (NE). Species known from only one sex, old material or not included in recent revisions, were designated as Data Deficient for either taxonomic reasons or the lack of Distribution Data (DD). Species with broad global distribution ranges (Categories 0-2) were considered to be of Least Concern (LC), while Categories 3 and 4 are considered to be South African endemics (SAE) and Category 5 is Limpopo endemics (SAE-LE).

\section{Results and discussion Numbers present}

A total of 47 families represented by 216 genera and 346 species have been recorded from the BB (Tables 2 and Appendix 1). A comprehensive account of the spider diversity of the Blouberg is provided in the form of a checklist (Appendix 1). This account adds 170 species to Blouberg since the account published by Muelelwa et al. (2010). This diversity is in excess of $150 \%$ more than the average of 228 species that were recorded in other studies in the Limpopo province, which range from 175 species in Nylsvley (Dippenaar-Schoeman \& Prendini 2009) to 286 species in the Makalali Nature Reserve (Whitmore et al. 2002). 

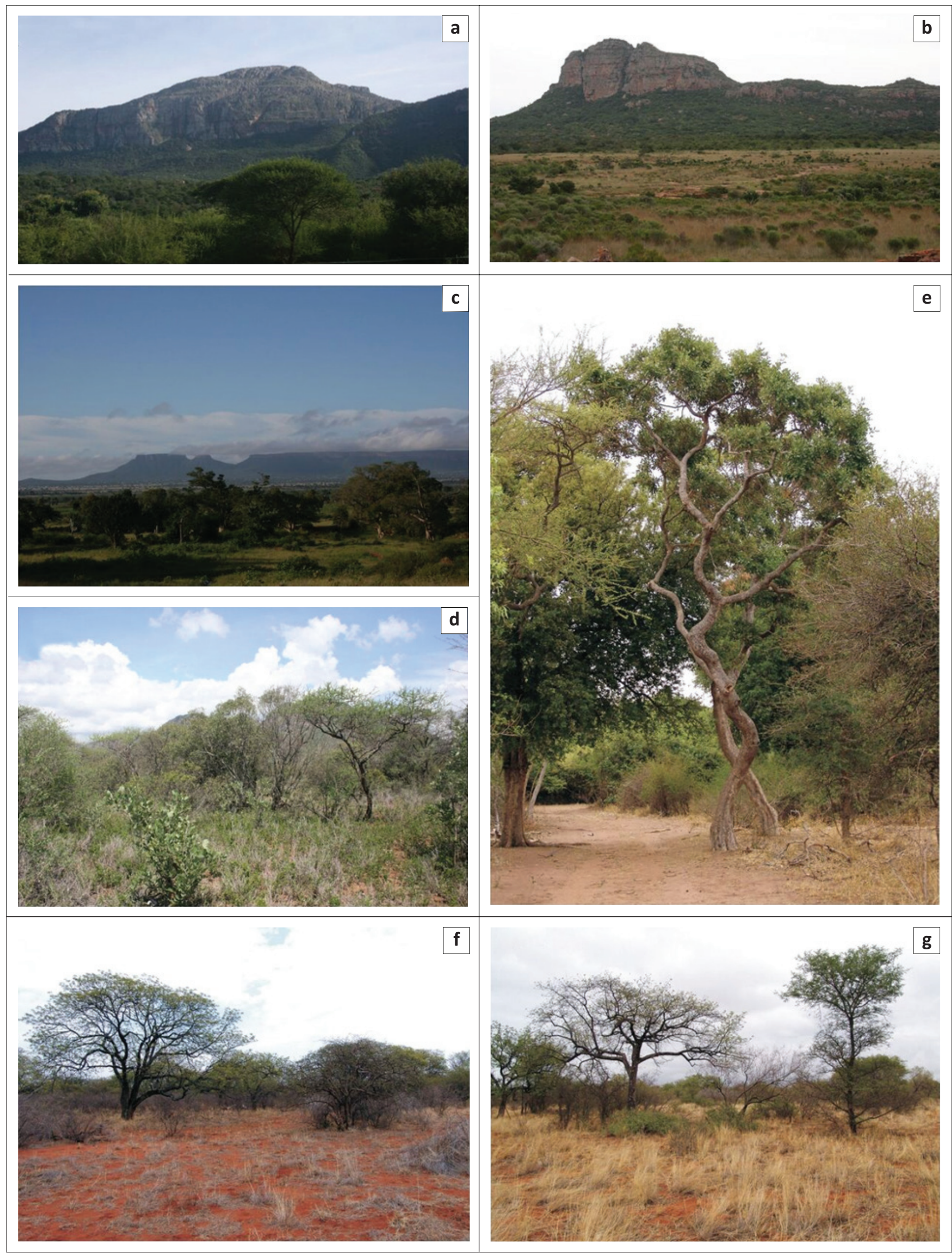

Source: All photos courtesy of Stefan Foord, except (e), (f), (g) by Norbert Hahn.

FIGURE 2: Habitat associated with the Blouberg: (a) southern aspect of the mountain, (b) grassland on top of the mountain, (c, d) foothills (south of the mountain), (e-g) foothills north of the mountain with deep sandy soil. 
TABLE 1: Conservation status and endemicity of the spider species sampled at the Blouberg.

\begin{tabular}{|c|c|c|c|}
\hline Category & No. spp. & Conservation status & $\%$ \\
\hline \multicolumn{4}{|l|}{ Conservation status } \\
\hline $\begin{array}{l}\text { Data Deficient (taxonomic reason or lack } \\
\text { of Distribution Data) }\end{array}$ & 12 & DD & 3.5 \\
\hline $\begin{array}{l}\text { Not Evaluated: Immature, new or } \\
\text { undetermined }\end{array}$ & 34 & NE & 9.8 \\
\hline Least Concern & 299 & LC & 86.4 \\
\hline Vulnerable & 1 & VU & 0.3 \\
\hline \multicolumn{4}{|l|}{ Endemicity } \\
\hline 0 - Africa and wider (C) & 21 & LC & 6.1 \\
\hline 1 - Africa endemics (AE) & 137 & LC & 39.6 \\
\hline 2 - Southern Africa endemics (STHE) & 90 & LC & 26.0 \\
\hline $\begin{array}{l}3 \text { - South Africa endemics (SAE): }>3 \\
\text { provinces }\end{array}$ & 52 & LC & 15.0 \\
\hline $\begin{array}{l}4 \text { - South Africa endemics (SAE): } \\
2 \text { adjacent provinces }\end{array}$ & 7 & LC/Rare & 2.0 \\
\hline 5 - Limpopo province endemics (LE) & 5 & $\mathrm{DD} /$ Rare & 1.4 \\
\hline 6 - Blouberg endemic (BBE) & 0 & Rare & 0.0 \\
\hline
\end{tabular}

No. spp., number of species; DD, Data Deficient; NE, Not Evaluated; LC, Least Concern VU, Vulnerable.

\section{Distribution and conservation concern}

Of the 346 species sampled, 12 are DD and lack taxonomic or distribution data, while 34 species $(9.8 \%$ ) were NE (Table 1 and Appendix 1). Fifteen species are possibly new to science and 16 species were undetermined because of the lack of a resolved taxonomy (Table 1). Many of the possibly new species fall within species-rich families that can only be confirmed after revisionary studies. Most of the remaining 299 species $(86.4 \%)$ are listed as LC. These large groups include $20 \mathrm{spp}$. (5.8\%) that are cosmopolitan and $139 \mathrm{spp}$. $(40.2 \%)$ that are found throughout Africa. A large proportion (153 spp., 44.2\%) are endemic to southern Africa, of which five $(1.4 \%)$ are Limpopo province endemics and $57(16.5 \%)$ are endemic to South Africa (Table 1). Only 64 (18.5\%) of the species are restricted to South Africa (Table 1). No endemic species are recorded for the Blouberg nor were any previous Soutpansberg endemic species recorded for the mountain.

The Blouberg Nature Reserve is the type locality of two Thomisidae species: Heriaeus peterwebbi Van Niekerk \& Dippenaar-Schoeman, 2013 (Figure 3c) and Mystaria savannensis Lewis \& Dippenaar-Schoeman, 2014 (Figure 2d). Five species are restricted to the Limpopo province and of special concern because of their restricted distribution (Appendix 1): Ammoxenus daedalus Dippenaar \& Meyer, 1980 (Ammoxenidae) (Figure 3a); Vendaphaea lajuma Haddad, 2009 (Corinnidae); Galeosoma vandami Hewitt, 1915 (Idiopidae) (Figure 3g); Segregara paucispinulosus (Hewitt, 1915) (Idiopidae) and Ballomma neethlingi Jocqué \& Henrard, 2015 (Zodariidae). Twenty spider species recorded on the Blouberg have a global distribution (World Spider Catalog 2019). Isoxya semiflava Simon, 1887 (Araneidae) and Phlegra procera Wesołowska \& Cumming, 2008 (Salticidae) are new records for South Africa (Appendix 1).

\section{Family diversity}

Similar to other studies in the Savanna Biome (Foord et al. 2011), Salticidae (46 spp.), Gnaphosidae (37 spp.), Thomisidae (31 spp.) and Araneidae (26 spp.) consistently dominate spider
TABLE 2: Spider diversity of Blouberg, with total number of genera and species sampled per family.

\begin{tabular}{|c|c|c|}
\hline Family & Genera & Species \\
\hline Agelenidae & 4 & 5 \\
\hline Amaurobiidae & 1 & 1 \\
\hline Ammoxenidae & 2 & 3 \\
\hline Araneidae & 17 & 26 \\
\hline Atypidae & 1 & 1 \\
\hline Barychelidae & 2 & 3 \\
\hline Caponiidae & 1 & 1 \\
\hline Cheiracanthiidae & 2 & 6 \\
\hline Clubionidae & 1 & 1 \\
\hline Corinnidae & 4 & 4 \\
\hline Ctenidae & 1 & 2 \\
\hline Cyatholipidae & 1 & 1 \\
\hline Cyrtaucheniidae & 1 & 1 \\
\hline Deinopidae & 1 & 1 \\
\hline Dictynidae & 3 & 3 \\
\hline Dipluridae & 2 & 2 \\
\hline Eresidae & 4 & 5 \\
\hline Gnaphosidae & 18 & 37 \\
\hline Hersiliidae & 1 & 3 \\
\hline Idiopidae & 4 & 6 \\
\hline Linyphiidae & 6 & 7 \\
\hline Liocranidae & 1 & 2 \\
\hline Lycosidae & 16 & 24 \\
\hline Mimetidae & 2 & 2 \\
\hline Mysmenidae & 1 & 1 \\
\hline Nemesiidae & 1 & 2 \\
\hline Oecobiidae & 1 & 1 \\
\hline Oonopidae & 1 & 1 \\
\hline Oxyopidae & 3 & 16 \\
\hline Palpimanidae & 2 & 3 \\
\hline Philodromidae & 7 & 13 \\
\hline Pholcidae & 3 & 3 \\
\hline Pisauridae & 5 & 6 \\
\hline Salticidae & 27 & 47 \\
\hline Scytodidae & 1 & 5 \\
\hline Segestriidae & 1 & 2 \\
\hline Selenopidae & 2 & 6 \\
\hline Sicariidae & 2 & 2 \\
\hline Sparassidae & 3 & 6 \\
\hline Tetragnathidae & 3 & 3 \\
\hline Theraphosidae & 2 & 2 \\
\hline Theridiidae & 17 & 23 \\
\hline Thomisidae & 19 & 31 \\
\hline Trachelidae & 5 & 6 \\
\hline Trochanteriidae & 1 & 1 \\
\hline Uloboridae & 5 & 5 \\
\hline Zodariidae & 8 & 18 \\
\hline Total & 216 & 346 \\
\hline
\end{tabular}

diversity in the Savanna Biome (Table 2 and Appendix 1). The salticids are active hunters and present in almost all habitat strata. Their silk retreats are utilised for molting, oviposition during periods of inactivity or occasionally for mating (Dippenaar-Schoeman 2014). Of the 46 spp. sampled, 26 spp. are new records for the Blouberg and one, Bianor albobimaculatus (Lucas, 1846), is also known from outside Africa (Mediterranean to Russia, Asia and India); 41 of the salticid species are listed as LC and 24 of them have a wide distribution throughout Africa, while 12 species are known only from southern Africa. Hasarinella distincta 

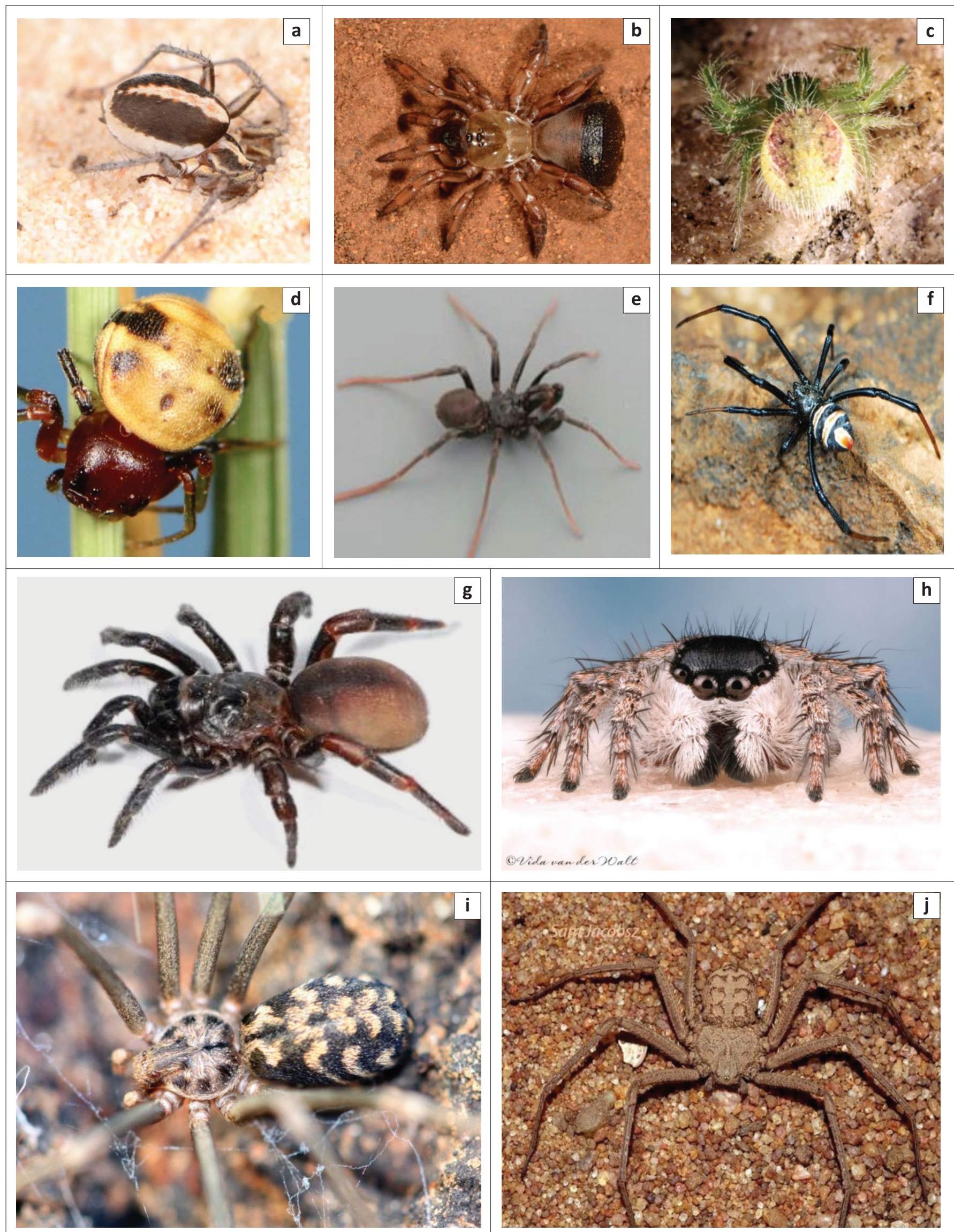

Source: All photos courtesy of Peter Webb, except (e) lan Engelbrecht, (h) Vida van der Walt.

FIGURE 3: Spiders of the Blouberg: (a) Ammoxenus daedalus (Ammoxenidae), (b) Galeosoma vandami (Idiopidae), (c) Heriaeus peterwebbi (Thomisidae), (d) Mystaria savannensis (Thomisidae), (e) Calommata transvaalensis male (Atypidae) (f) Latrodectus renivulvatus (Theridiidae), (g) Idiops castaneus (Idiopidae), (h) New species (Salticidae), (i) Loxosceles simillima (Sicaridae), (j) Hexophthalma hahnidae (Sicariidae). 
Haddad \& Wesołowska, 2013 and Tomomingi szutsi Wesołowska \& Haddad, 2013, are only known from Limpopo and Mpumalanga provinces. Two salticid species, one in the subfamily Aelurullinae (Figure 3f) and the other in the genus Rhene, are possibly new to science, while a species previously only known from Zimbabwe, Phlegra procera Wesołowska \& Cumming, 2008, was recorded in South Africa for the first time (Appendix 1).

Gnaphosids are free-living spiders found mainly on the soil surface, represented by 32 species belonging to 13 genera (Table 2 and Appendix 1). The most diverse gnaphosid genera are the Asemesthes (6 spp.) and Zelotes (10 spp.). Both genera are particularly common in the arid regions of South Africa. Of the 32 species sampled, 11 are new records for the Blouberg. One of these species, Odontodrassus aphanes (Thorell, 1897), is widely distributed and previously only known from the Seychelles, Myanmar to Japan, New Caledonia, French Polynesia and was introduced to Jamaica. This is also the first record for this species in South Africa. Twenty-eight of the species are listed as LC and only seven are widely distributed throughout Africa, while 15 species are restricted to southern Africa. Six species are only known from South Africa, three of these species belong to the genera Leptodrassex, Trephopoda and Xerophaeus and are possibly new to science.

Thomisids are sit-and-wait predators, largely restricted to grass, shrubs, flowers and trees, while few are associated with the ground surface. On the Blouberg, 19 genera represented by 31 spp. were sampled (Table 2 and Appendix 1 ). Thomisids easily disperse by wind as evidenced by the fact that 30 of the 31 known species are widely distributed throughout Africa. Although Blouberg is the type locality of Heriaeus peterwebbi (Figure 3c) and Mystaria savannensis (Figure 3d), both species have a wide African distribution and only Pherecydes lucinae Dippenaar-Schoeman, 1980, is restricted to South Africa.

Araneids are commonly known for their orb webs. Twentysix species from 17 genera are known from the Blouberg (Table 2 and Appendix 1). The taxonomy of African genera are unresolved and the generic positions of two species listed here are uncertain, while three species are possibly new to science. Twenty-one species are widely distributed throughout Africa and three species, namely Cyrtophora citricola (Forskål, 1775), Hypsosinga pygmaea (Sundevall, 1831) and Hypsosinga albovillata (Westring, 1851), have a worldwide distribution. Cyclosa elongatus (Lawrence, 1947) is the only species with a distribution restricted to South African, while Isoxya semiflava Simon, 1887, previously known from West and Central Africa, is a new record for South Africa.

Other species of concern include Calommata transvaalica Hewitt, 1916 (Atypidae) (Figure 3e), which was described in 1916 from Roodeplaat, Gauteng, and is restricted to South Africa. It is presently only known from Gauteng (few localities around Pretoria) and Limpopo provinces (Soutpansberg and Blouberg) (Fourie et al. 2011). Despite several surveys, the species has so far not been found in intervening areas. The last female was sampled in 1915. Habitat loss in Gauteng because of crop cultivation and urban development is a concern as the species is suspected to occur at fewer than ten locations. Calommata transvaalica is therefore listed as Vulnerable under the VU B2ab (i, ii, iii, iv) criterion (IUCN 2001).

Five of the South African spiders of medical importance were sampled from the BB: Cheiracanthium furculatum Karsch, 1879 (sac spider); Hexophthalma hahni (Karsch, 1878) (six-eyed sand spider, Figure 3j); Loxosceles simillima Lawrence, 1927 (violin spider, Figure 3i) and two button spiders, Latrodectus geometricus C.L.Koch, 1841 and L. renivulvatus Dahl, 1902 (Figure 3f).

\section{Conclusion}

Although no species are endemic to the Blouberg, the mountain harbours several unidentified taxa. Five species recorded in the study are restricted to Limpopo province, all of which have a small distribution range and are therefore of special concern. These five species were all recorded from deep sandy soils on the foothills of the mountain, pointing to the importance of this habitat for spider conservation. The small number of national records $(<4$ per species) limits our ability to extrapolate their distribution beyond their current range. The conservation importance of this habitat is further supported by the recent discovery of the endemic darkling beetle Anaxius bloubergensis Kamiński \& Schoeman 2018 from the Blouberg Nature Reserve. As more than $90 \%$ of collecting effort was concentrated on the foothills of the mountain, future studies should focus on the higher elevations of the mountain, as the majority of newly discovered and endemic species on the neighbouring Soutpansberg, are found at higher elevations (Foord et al. 2008). The biggest threats to spider diversity in the region are climate change, the removal of Afromontane forests on the eastern aspect of the mountain, and increased urbanisation and agricultural activities on the foothills of the mountain.

\section{Acknowledgements}

The authors would like to thank the Agricultural Research Council (ARC); the South African National Biodiversity Institute (SANBI), Threatened Species Programme for funding the South African National Survey of Arachnida (SANSA) Phase 2; the officials of Blouberg Nature Reserve, Johan van Wyk in particular, for their friendliness and assistance; the staff of the Arachnology Biosystematics Programme, ARC - Plant Health and Protection for their assistance with processing and databasing the material collected. A special thanks to all the people who assisted with fieldwork: V. Gelebe, M. Muthapuli (Univen SANSA team) and the identification of species: T. RussellSmith (UK) and Galina Azarkina (Russia). The first three authors acknowledge support from the NRF Incentive 
Funding and the first author from the DST-NRF Centre for Invasion Biology.

\section{Competing interests}

The authors declare that they have no financial or personal relationships that may have inappropriately influenced them in writing this article.

\section{Authors' contributions}

S.F. undertook and organised the SANSA survey and assist in writing up the article. A.S.D.-S. is the SANSA project manager; she did most of the identifications, conservation assessment and wrote the first draft of the article. C.R.H. is the SANSA assistant project manager who assists with the identification of some families and editing of the article. C.S. undertook part of the surveys. N.H. undertook part of the survey and assisted on the biodiversity aspects of this article. R.L. assisted with the curation and databasing of the sampled material.

\section{Ethical considerations}

Animals were collected under permit no. CPM-005-00005, provided by the Department of Environmental Affairs, South Africa.

\section{Funding}

The authors would like to thank the DST-NRF Centre of Excellence for Invasion Biology, through the South African Research Chairs Initiative Chair on Biodiversity Value and Change in the Vhembe Biosphere Reserve, hosted by the University of Venda.

\section{Data availability statement}

Data sharing is not applicable to this article as no new data were created or analysed in this study.

\section{Disclaimer}

The views and opinions expressed in this article are those of the authors and do not necessarily reflect the official policy or position of any affiliated agency of the authors.

\section{References}

Dippenaar-Schoeman, A.S., Haddad, C.R., Foord, S.H., Lyle, R., Lotz, L.N. \& Marais, P., 2015, 'South African National Survey of Arachnida (SANSA): Review of current knowledge, constraints and future needs for documenting spider diversity (Arachnida: Araneae)', Transactions of the Royal Society of South Africa 70(3), 245-275. https://doi.org/10.1080/0035919X.2015.1088486

Dippenaar-Schoeman, A.S. \& Prendini, L., 2009, 'Spiders and scorpions (Arachnida; Araneae, Scorpiones) of the Nylsvley Nature Reserve, South Africa', Koedoe 51(1), 1-9. https://doi.org/10.4102/koedoe.v51i1.161

Dippenaar-Schoeman, A.S., 2014, Field guide of the spiders of South Africa, Lapa Publishers, Pretoria.

Foord, S.H., Dippenaar-Schoeman, A.S., Haddad, C.R., Lotz, L. \& Lyle, R., 2011, 'The faunistic diversity of spiders (Arachnida: Araneae) of the Savanna Biome in South Africa', Transactions of the Royal Society of South Africa 66(3), 170-201. https:// Africa, Transactions of the Royal Society
doi.org/10.1080/0035919X.2011.639406

Foord, S.H., Dippenaar-Schoeman, A.S. \& Stam, E.M., 2013, 'Surrogates of spider diversity, leveraging the conservation of a poorly known group in the Savanna Biome of South Africa', Biological Conservation 161, 203-212. https://doi. org/10.1016/j.biocon.2013.02.011

Foord, S.H., Mafadza, M., Dippenaar-Schoeman, A.S. \& Van Rensburg, B.J., 2008 'Micro-scale heterogeneity of spiders (Arachnida: Araneae) in the Soutpansberg, South Africa: A comparative survey and inventory in representative habitats', African Zoology 43(2), 156-174. https://doi.org/10.3377/1562-7020-43.2.156

Fourie, R., Haddad, C.R. \& Jocqué, R., 2011, 'A revision of the purse web spider genus Calommata Lucas, 1837 (Araneae: Atypidae) in the Afrotropical Region', Zookeys 95, 1-28. https://doi.org/10.3897/zookeys.95.745

Hahn, N., 2011, 'Refinement of the Soutpansberg Geomorphic Province, Limpopo, South Africa', Transactions of the Royal Society of South Africa 66(1), 32-40. https://doi.org/10.1080/0035919X.2011.566422

International Union for Conservation of Nature (IUCN) Species Survival Commission, International Union for Conservation of Nature, \& Natural Resources, 2001, IUCN Red List categories and criteria, IUCN.

Kamiński, M.J. \& Schoeman, C.S., 2018, 'Taxonomic revision of a darkling beetles genus Anaxius (Tenebrionidae: Pedinini: Helopinina)', Zootaxa 4455, 471-485.

Mostert, T.H.C., Bredenkamp, G.J., Klopper, H.L., Verwey, C., Mostert, R.E. \& Hahn, N., 2008, 'Major vegetation types of the Soutpansberg Conservancy and the Blouberg Nature Reserve, South Africa'. Koedoe 50(1), 32-48. https://doi.org/10.4102/ koedoe.v50i1.125

Muelelwa, M., Foord, S.H., Dippenaar-Schoeman, A.S. \& Stam, E.M., 2010, 'Towards a standardized and optimized protocol for rapid biodiversity assessments: spider species richness and assemblage composition in two savanna vegetation types', African Zoology 45(2), 273-290. https://doi.org/10.3377/004.045.0206

Whitmore, C., Slotow, R., Crouch, T.E. \& Dippenaar-Schoeman, A.S., 2002, 'Diversity of spiders (Araneae) in a Savanna reserve, Northern Province, South Africa', Journal of Arachnology 30(2), 344-356. https://doi.org/10.1636/0161-8202(2002)030 [0344:DOSAIA]2.0.CO;2

World Spider Catalog, 2019, World Spider Catalog, Version 20.0, Natural History Museum Bern, viewed 22 April 2019, from http://wsc.nmbe.ch. 


\section{Appendix 1}

TABLE 1-A1: Checklist of the spiders of Blouberg showing endemicity value (EV), conservation status (CS) and distribution (Dist).

\begin{tabular}{|c|c|c|c|c|}
\hline Family & Species & EV & CS & Dist \\
\hline \multirow[t]{5}{*}{ Agelenidae } & Agelena gaerdesi Roewer, 1955 & 2 & LC & STHE \\
\hline & Benoitia sp. 4 (new) & NE & - & - \\
\hline & Benoitia ocellata (Pocock, 1900) & 1 & LC & $\mathrm{AE}$ \\
\hline & Mistaria leucopyga (Pavesi, 1883) & 1 & LC & $\mathrm{AE}$ \\
\hline & Olorunia punctata Lehtinen, 1967 & 1 & LC & AE \\
\hline Amaurobiidae & Chresiona invalida (Simon, 1898) & 3 & LC & SAE \\
\hline \multirow[t]{3}{*}{ Ammoxenidae } & Ammoxenus daedalus Dippenaar \& Meyer, 1980 & 5 & DD & SAE-LE \\
\hline & Ammoxenus psammodromus Simon, 1910 & 2 & LC & STHE \\
\hline & Rastellus florisbad Platnick \& Griffin, 1990 & 3 & DD & SAE \\
\hline \multirow[t]{23}{*}{ Araneidae } & Araneus apricus (Karsch, 1884) & 1 & LC & $\mathrm{AE}$ \\
\hline & Araneus holzapfelae Lessert, 1936 & 1 & LC & AE \\
\hline & Araneus legonensis Grasshoff \& Edmunds, 1979 & 1 & LC & AE \\
\hline & Argiope australis (Walckenaer, 1805) & 1 & LC & AE \\
\hline & Caerostris sexcuspidata (Fabricius, 1793) & 1 & LC & AE \\
\hline & Cyphalonatus larvatus (Simon, 1881) & 1 & LC & $\mathrm{AE}$ \\
\hline & Cyrtophora citricola (Forskål, 1775) & 0 & LC & C \\
\hline & Hypsosinga albovillata (Westring, 1851) & 0 & LC & $\mathrm{AE}$ \\
\hline & Hypsosinga lithyphantoides Caporiacco, 1947 & 1 & LC & $\mathrm{AE}$ \\
\hline & Hypsosinga pygmaea (Sundevall, 1831) & 0 & LC & C \\
\hline & Isoxya semiflava Simon, 1887 & 1 & LC & $\mathrm{AE}$ \\
\hline & Nemoscolus cotti Lessert, 1933 & 2 & LC & STHE \\
\hline & Nemoscolus tubicola (Simon, 1887) & 2 & LC & STHE \\
\hline & Nemoscolus sp. (new) & $\mathrm{NE}$ & - & - \\
\hline & Neoscona blondeli (Simon, 1885) & 1 & LC & $\mathrm{AE}$ \\
\hline & Neoscona subfusca (C.L. Koch, 1837) & 1 & LC & $\mathrm{AE}$ \\
\hline & Neoscona triangula (Keyserling, 1864) & 1 & LC & $\mathrm{AE}$ \\
\hline & Nephila fenestrata Thorell, 1859 & 2 & LC & STHE \\
\hline & Nephila senegalensis annulata (Walckenaer, 1842) & 2 & LC & STHE \\
\hline & Pycnacantha tribulus (Fabricius, 1781) & 2 & LC & STHE \\
\hline & Ursa turbinata Simon, 1895 & 3 & LC & SAE \\
\hline & Araneidae sp. 6 (undetermined) & $\mathrm{NE}$ & - & - \\
\hline & Araneidae sp. 7 (undetermined) & $\mathrm{NE}$ & - & - \\
\hline Atypidae & Calommata transvaalica Hewitt, 1916 & 4 & VU & SAE \\
\hline \multirow[t]{3}{*}{ Barychelidae } & Pisenor arcturus (Tucker, 1917) & 2 & LC & STHE \\
\hline & Pisenor notius Simon, 1889 & 1 & LC & $\mathrm{AE}$ \\
\hline & Sipalolasma humicola (Benoit, 1965) & 1 & LC & $\mathrm{AE}$ \\
\hline Caponiidae & Caponia chelifera Lessert, 1936 & 2 & LC & STHE \\
\hline \multirow[t]{6}{*}{ Cheiracanthiidae } & Cheiracanthium angolensis Lotz, 2007 & 2 & LC & STHE \\
\hline & Cheiracanthium furculatum Karsch, 1879 & 1 & LC & $\mathrm{AE}$ \\
\hline & Cheiracanthium schenkeli Caporiacco, 1949 & 1 & LC & $\mathrm{AE}$ \\
\hline & Cheiracanthium vansoni Lawrence, 1936 & 1 & LC & $A E$ \\
\hline & Cheiramiona krugerensis Lotz, 2002 & 3 & LC & SAE \\
\hline & Cheiramiona paradisus Lotz, 2002 & 2 & LC & STHE \\
\hline Clubionidae & Clubiona abbajensis Strand, 1906 & 1 & LC & $\mathrm{AE}$ \\
\hline \multirow[t]{4}{*}{ Corinnidae } & Coenoptychus tropicalis (Haddad, 2004) & 1 & LC & $\mathrm{AE}$ \\
\hline & Cambalida dippenaarae Haddad, 2012 & 1 & LC & $\mathrm{AE}$ \\
\hline & Copa flavoplumosa Simon, 1885 & 1 & LC & $\mathrm{AE}$ \\
\hline & Vendaphaea lajuma Haddad, 2009 & 5 & DD & SAE-LE \\
\hline \multirow[t]{2}{*}{ Ctenidae } & Ctenus pulchriventris (Simon, 1896) & 2 & LC & STHE \\
\hline & Ctenus transvaalensis Benoit, 1981 & 3 & LC & SAE \\
\hline Cyatholipidae & Cyatholipus isolatus Griswold, 1987 & 4 & DD & SAE \\
\hline Cyrtaucheniidae & Ancylotrypa brevipalpis (Hewitt, 1916) & 3 & LC & SAE \\
\hline Deinopidae & Menneus camelus Pocock, 1902 & 3 & LC & SAE \\
\hline \multirow[t]{3}{*}{ Dictynidae } & Archaeodictyna ulova Griswold \& Meikle-Griswold, 1987 & 3 & LC & SAE \\
\hline & Dictyna sp. 1 (undetermined) & $\mathrm{NE}$ & - & - \\
\hline & Mashimo leleupi Lehtinen, 1967 & 1 & LC & $\mathrm{AE}$ \\
\hline
\end{tabular}


TABLE 1-A1 (Continues...): Checklist of the spiders of Blouberg showing endemicity value (EV), conservation status (CS) and distribution (Dist).

\begin{tabular}{|c|c|c|c|c|}
\hline Family & Species & EV & CS & Dist \\
\hline \multirow[t]{2}{*}{ Dipluridae } & Allothele malawi Coyle, 1984 & 1 & LC & $\mathrm{AE}$ \\
\hline & Thelechoris striatipes (Simon, 1889) & 1 & LC & $\mathrm{AE}$ \\
\hline \multirow[t]{5}{*}{ Eresidae } & Dresserus colsoni Tucker, 1920 & 3 & LC & SAE \\
\hline & Gandanameno fumosa (C. L. Koch, 1837) & 3 & LC & SAE \\
\hline & Paradonea parva (Tucker, 1920) & 2 & LC & STHE \\
\hline & Paradonea presleyi Miller et al., 2012 & 2 & LC & STHE \\
\hline & Stegodyphus africanus (Blackwall, 1866) & 1 & LC & $\mathrm{AE}$ \\
\hline \multirow[t]{29}{*}{ Gnaphosidae } & Aneplasa interrogationis Tucker, 1923 & 3 & DD & SAE \\
\hline & Asemesthes ceresicola Tucker, 1923 & 3 & LC & SAE \\
\hline & Asemesthes numisma Tucker, 1923 & 2 & LC & STHE \\
\hline & Asemesthes pallidus Purcell, 1908 & 3 & LC & SAE \\
\hline & Asemesthes paynteri Tucker, 1923 & 3 & LC & SAE \\
\hline & Asemesthes purcelli Tucker, 1923 & 2 & LC & STHE \\
\hline & Asemesthes reflexus Tucker, 1923 & 3 & LC & SAE \\
\hline & Camillina pavesii (Simon, 1897) & 1 & LC & $\mathrm{AE}$ \\
\hline & Echemus erutus Tucker, 1923 & 2 & LC & STHE \\
\hline & Ibala arcus (Tucker, 1923) & 2 & LC & STHE \\
\hline & Ibala bilinearis (Tucker, 1923) & 2 & LC & STHE \\
\hline & Leptodrassex sp. 1 (new) & $\mathrm{NE}$ & - & - \\
\hline & Nomisia tubula (Tucker, 1923) & 2 & LC & STHE \\
\hline & Nomisia varia (Tucker, 1923) & 2 & LC & STHE \\
\hline & Odontodrassus aphanes (Thorell, 1897) & 0 & LC & C \\
\hline & Pterotrichia auris (Tucker, 1923) & 2 & LC & STHE \\
\hline & Scotophaeus marleyi Tucker, 1923 & 3 & LC & SAE \\
\hline & Trephopoda parvipalpa (Tucker, 1923) & 2 & LC & STHE \\
\hline & Trephopoda sp. 2 (new) & $\mathrm{NE}$ & - & - \\
\hline & Xerophaeus aurariarum Purcell, 1907 & 2 & LC & STHE \\
\hline & Xerophaeus sp. (new) & $\mathrm{NE}$ & - & - \\
\hline & Zelotes chinguli Fitzpatrick, 2007 & 2 & LC & STHE \\
\hline & Zelotes corrugatus (Purcell, 1907) & 1 & LC & $A E$ \\
\hline & Zelotes fuligineus (Purcell, 1907) & 1 & LC & $\mathrm{AE}$ \\
\hline & Zelotes lavus Tucker, 1923 & 2 & LC & STHE \\
\hline & Zelotes natalensis Tucker, 1923 & 2 & LC & STHE \\
\hline & Zelotes pallidipes Tucker, 1923 & 2 & LC & STHE \\
\hline & Zelotes scrutatus (O.P.-Cambridge, 1872) & 1 & LC & $\mathrm{AE}$ \\
\hline & Zelotes tuckeri Roewer, 1951 & 1 & LC & $\mathrm{AE}$ \\
\hline \multirow[t]{3}{*}{ Hersiliidae } & Hersilia arborea Lawrence, 1928 & 2 & LC & STHE \\
\hline & Hersilia sericea Pocock, 1898 & 1 & LC & $A E$ \\
\hline & Hersilia setifrons Lawrence, 1928 & 2 & LC & STHE \\
\hline \multirow[t]{6}{*}{ Idiopidae } & Ctenolophus fenoulheti Hewitt, 1913 & 3 & LC & SAE \\
\hline & Ctenolophus sp. 2 (new) & $\mathrm{NE}$ & - & - \\
\hline & Ctenolophus sp. 3 (new) & NE & - & - \\
\hline & Galeosoma vandami Hewitt, 1915 & 5 & LC & SAE-LE \\
\hline & Idiops castaneus Hewitt, 1913 & 4 & DD & SAE \\
\hline & Segregara paucispinulosus (Hewitt, 1915) & 5 & DD & SAE-LE \\
\hline \multirow[t]{7}{*}{ Linyphiidae } & Agyneta habra (Locket, 1968) & 1 & LC & $\mathrm{AE}$ \\
\hline & Agyneta natalensis (Jocqué, 1984) & 3 & LC & SAE \\
\hline & Mecynidis dentipalpis Simon, 1894 & 2 & LC & STHE \\
\hline & Metaleptyphantes perexiguus (Simon \& Fage, 1922) & 1 & LC & $\mathrm{AE}$ \\
\hline & Pelecopsis janus Jocqué, 1984 & 2 & LC & STHE \\
\hline & Tybaertiella krugeri (Simon, 1894) & 1 & LC & $\mathrm{AE}$ \\
\hline & Erigoninae sp. 1 (undetermined) & $\mathrm{NE}$ & - & - \\
\hline \multirow[t]{2}{*}{ Liocranidae } & Rhaeboctesis exilis Tucker, 1920 & 3 & LC & SAE \\
\hline & Rhaeboctesis trinotatus Tucker, 1920 & 2 & LC & STHE \\
\hline \multirow[t]{2}{*}{ Lycosidae } & Allocosa exserta Roewer, 1959 & 2 & LC & STHE \\
\hline & Allocosa lawrencei (Roewer, 1951) & 2 & LC & STHE \\
\hline
\end{tabular}


TABLE 1-A1 (Continues...): Checklist of the spiders of Blouberg showing endemicity value (EV), conservation status (CS) and distribution (Dist).

\begin{tabular}{|c|c|c|c|c|}
\hline Family & Species & EV & CS & Dist \\
\hline & Evippomma squamulatum (Simon, 1898) & 2 & LC & STHE \\
\hline & Foveosa foveolata (Purcell, 1903) & 1 & LC & $A E$ \\
\hline & Hippasa australis Lawrence, 1927 & 1 & LC & $\mathrm{AE}$ \\
\hline & Hippasa elienae Alderweireldt \& Jocqué, 2005 & 1 & LC & $\mathrm{AE}$ \\
\hline & Hogna bimaculata (Purcell, 1903) & 2 & LC & STHE \\
\hline & Hogna spenceri (Pocock, 1898) & 1 & LC & $\mathrm{AE}$ \\
\hline & Hogna transvaalica (Simon, 1898) & 3 & LC & SAE \\
\hline & Minicosa neptuna Alderweireldt \& Jocqué, 2007 & 3 & LC & STHE \\
\hline & Ocyale guttata (Karsch, 1878) & 1 & LC & $\mathrm{AE}$ \\
\hline & Pardosa crassipalpis Purcell, 1903 & 1 & LC & $\mathrm{AE}$ \\
\hline & Pardosa leipoldti Purcell, 1903 & 2 & LC & STHE \\
\hline & Pardosa manubriata Simon, 1898 & 2 & LC & STHE \\
\hline & Proevippa albiventris (Simon, 1898) & 2 & LC & STHE \\
\hline & Proevippa fascicularis (Purcell, 1903) & 2 & LC & STHE \\
\hline & Trabea heteroculata Strand, 1913 & 1 & LC & $\mathrm{AE}$ \\
\hline & Trabea purcelli Roewer, 1951 & 1 & LC & $\mathrm{AE}$ \\
\hline & Zenonina albocaudata Lawrence, 1952 & 3 & LC & SAE \\
\hline & Lycosinae sp. 1 (undetermined) & $\mathrm{NE}$ & - & - \\
\hline & Trochosinae sp. 1 (undetermined) & $\mathrm{NE}$ & - & - \\
\hline \multirow[t]{2}{*}{ Mimetidae } & Ero lawrencei Unzicker, 1966 & 2 & LC & - \\
\hline & Mimetus sp. 1 (new) & $\mathrm{NE}$ & - & - \\
\hline Mysmenidae & Isela sp. 1 (undetermined) & $\mathrm{NE}$ & - & - \\
\hline \multirow[t]{2}{*}{ Nemesiidae } & Hermacha mazoena Hewitt, 1915 & 2 & LC & STHE \\
\hline & Hermacha sp. 2 (new) & $\mathrm{NE}$ & - & - \\
\hline Oecobiiidae & Uroecobius ecribellatus Kullmann \& Zimmermann, 1976 & 3 & LC & SAE \\
\hline Oonopidae & Gamasomorpha australis Hewitt, 1915 & 3 & LC & SAE \\
\hline \multirow[t]{14}{*}{ Oxyopidae } & Hamataliwa kulczynskii (Lessert, 1915) & 1 & LC & $\mathrm{AE}$ \\
\hline & Hamataliwa rufocaligata Simon, 1898 & 1 & LC & $\mathrm{AE}$ \\
\hline & Oxyopes dumonti Vinson, 1863 & 1 & LC & $\mathrm{AE}$ \\
\hline & Oxyopes falconeri Lessert, 1915 & 1 & LC & $\mathrm{AE}$ \\
\hline & Oxyopes flavipalpis (Lukas, 1858) & 1 & LC & $\mathrm{AE}$ \\
\hline & Oxyopes hoggi Lessert, 1915 & 1 & LC & $\mathrm{AE}$ \\
\hline & Oxyopes jacksoni Lessert, 1915 & 1 & LC & $\mathrm{AE}$ \\
\hline & Oxyopes longispinosus Lawrence, 1938 & 3 & LC & $\mathrm{AE}$ \\
\hline & Oxyopes pallidecoloratus Strand, 1906 & 1 & LC & $\mathrm{AE}$ \\
\hline & Oxyopes russoi Caporiacco, 1940 & 1 & LC & $\mathrm{AE}$ \\
\hline & Oxyopes schenkeli Lessert, 1927 & 1 & LC & $\mathrm{AE}$ \\
\hline & Oxyopes sp. 3 (undetermined) & NE & - & - \\
\hline & Oxyopes sp. 4 (undetermined) & NE & - & - \\
\hline & Peucetia crucifera Lawrence, 1927 & 2 & LC & STHE \\
\hline \multirow[t]{3}{*}{ Palpimanidae } & Diaphorocellus biplagiatus Simon, 1893 & 2 & LC & STHE \\
\hline & Palpimanus pseudarmatus Lawrence, 1952 & 3 & LC & SAE \\
\hline & Palpimanus transvaalicus Simon, 1893 & 3 & LC & SAE \\
\hline \multirow[t]{13}{*}{ Philodromidae } & Gephyrota glauca (Jézéquel, 1966) & 1 & LC & $\mathrm{AE}$ \\
\hline & Hirriusa variegata (Simon, 1895) & 3 & LC & SAE \\
\hline & Philodromus bigibbus australis Lawrence, 1928 & 3 & LC & SAE \\
\hline & Philodromus browningi Lawrence, 1952 & 2 & LC & STHE \\
\hline & Philodromus guineensis Millot, 1941 & 1 & LC & $\mathrm{AE}$ \\
\hline & Philodromus sp. 1 (undetermined) & NE & - & - \\
\hline & Suemus punctatus Lawrence, 1938 & 2 & LC & STHE \\
\hline & Thanatus dorsilineatus Jézéquel, 1964 & 1 & LC & $\mathrm{AE}$ \\
\hline & Thanatus vulgaris Simon, 1870 & 0 & LC & C \\
\hline & Tibellus australis (Simon, 1910) & 2 & LC & STHE \\
\hline & Tibellus cobusi Van den Berg \& Dippenaar-Schoeman, 1994 & 1 & LC & $\mathrm{AE}$ \\
\hline & Tibellus minor Lessert, 1919 & 1 & LC & $\mathrm{AE}$ \\
\hline & gen. n. sp.n. (nw) & $\mathrm{NE}$ & - & - \\
\hline
\end{tabular}


TABLE 1-A1 (Continues...): Checklist of the spiders of Blouberg showing endemicity value (EV), conservation status (CS) and distribution (Dist).

\begin{tabular}{|c|c|c|c|c|}
\hline Family & Species & EV & CS & Dist \\
\hline \multirow[t]{3}{*}{ Pholcidae } & Quamtana hectori Huber, 2003 & 3 & LC & SAE \\
\hline & Smeringopus natalensis Lawrence, 1947 & 2 & LC & STHE \\
\hline & Spermophora sp. 1 (immature) & $\mathrm{NE}$ & - & - \\
\hline \multirow[t]{6}{*}{ Pisauridae } & Afropisaura rothiformis (Strand, 1908) & 1 & LC & $\mathrm{AE}$ \\
\hline & Euprosthenops australis Simon, 1898 & 1 & LC & $\mathrm{AE}$ \\
\hline & Euprosthenopsis vuattouxi Blandin, 1977 & 1 & LC & $\mathrm{AE}$ \\
\hline & Maypacius roeweri Blandin, 1975 & 1 & LC & $\mathrm{AE}$ \\
\hline & Nilus margaritatus (Pocock, 1898) & 1 & LC & $\mathrm{AE}$ \\
\hline & Nilus massajae (Pavesi, 1883) & 1 & LC & $\mathrm{AE}$ \\
\hline \multirow[t]{5}{*}{ Prodidomidae } & Austrodomus scaber (Purcell, 1904) & 2 & LC & STHE \\
\hline & Prodidomus capensis Purcell, 1904 & 3 & LC & SAE \\
\hline & Theuma fusca Purcell, 1907 & 2 & LC & STHE \\
\hline & Theuma maculata Purcell, 1907 & 2 & LC & STHE \\
\hline & Theuma sp. 1 (undetermined) & $\mathrm{NE}$ & - & - \\
\hline \multirow{43}{*}{ Salticidae } & Afraflacilla altera (Wesołowska, 2000) & 2 & LC & STHE \\
\hline & Asemonea clara Wesołowska \& Haddad, 2013 & 3 & LC & SAE \\
\hline & Bianor albobimaculatus (Lucas, 1846) & 0 & LC & $\mathrm{C}$ \\
\hline & Cyrba lineata Wanless, 1984 & 2 & LC & STHE \\
\hline & Cyrba nigrimana Simon, 1900 & 3 & LC & SAE \\
\hline & Evarcha ignea Wesołowska \& Cumming, 2008 & 1 & LC & $A E$ \\
\hline & Evarcha prosimilis Weslowska \& Cumming, 2008 & 1 & LC & $\mathrm{AE}$ \\
\hline & Hasarinella distincta Haddad \& Wesołowska, 2013 & 4 & LC & SAE \\
\hline & Heliophanus deamatus Peckham \& Peckham, 1903 & 2 & LC & STHE \\
\hline & Heliophanus proszynski Wesołowska, 2003 & 2 & LC & STHE \\
\hline & Heliophanus trepidus Simon, 1910 & 2 & LC & STHE \\
\hline & Holcolaetis zuluensis Lawrence, 1937 & 1 & LC & $\mathrm{AE}$ \\
\hline & Hyllus argyrotoxus Simon, 1902 & 1 & LC & $\mathrm{AE}$ \\
\hline & Hyllus brevitarsis Simon, 1902 & 1 & LC & $\mathrm{AE}$ \\
\hline & Iranattus principalis Wesołowska 2000 & 1 & LC & $\mathrm{AE}$ \\
\hline & Menemerus eburnensis Berland \& Millot, 1941 & 1 & LC & $\mathrm{AE}$ \\
\hline & Menemerus fagei Berland \& Millot, 1941 & 1 & LC & $\mathrm{AE}$ \\
\hline & Menemerus minshullae Wesołowska, 1999 & 1 & LC & $\mathrm{AE}$ \\
\hline & Menemerus zimbabwensis Weslowska, 1999 & 2 & LC & STHE \\
\hline & Mexcala elegans Peckham \& Peckham, 1903 & 1 & LC & $\mathrm{AE}$ \\
\hline & Myrmarachne ichneumon Simon, 1886 & 1 & LC & $\mathrm{AE}$ \\
\hline & Natta horizontalis Karsch, 1879 & 1 & LC & $\mathrm{AE}$ \\
\hline & Pachyballus transversus Simon, 1900 & 1 & LC & $\mathrm{AE}$ \\
\hline & Pellenes bulawayoensis Wesołowska, 1999 & 2 & LC & STHE \\
\hline & Pellenes tharinae Wesołowska, 2006 & 2 & LC & STHE \\
\hline & Phintella lajuma Haddad \& Wesołowska, 2013 & 3 & $\mathrm{DD}$ & SAE \\
\hline & Phlegra simplex Wesołowska \& Russell-Smith, 2000 & 1 & LC & $A E$ \\
\hline & Phlegra varia Wesołowska \& Russel-Smith, 2000 & 1 & LC & $A E$ \\
\hline & Phlegra procera Wesołowska \& Cumming, 2008 & 2 & LC & STHE \\
\hline & Pignus simoni (Peckham \& Peckham 1903) & 2 & LC & STHE \\
\hline & Portia schultzi Karsch, 1878 & 1 & LC & $A E$ \\
\hline & Rhene sp. 1 (new) & $\mathrm{NE}$ & - & - \\
\hline & Stenaelurillus guttiger (Simon, 1901) & 2 & LC & STHE \\
\hline & Thyene inflata (Gerstaecker, 1873) & 1 & LC & $\mathrm{AE}$ \\
\hline & Thyene natalii Peckham \& Peckham, 1903 & 1 & LC & $\mathrm{AE}$ \\
\hline & Thyene ogdeni Peckham \& Peckham, 1903 & 1 & LC & $\mathrm{AE}$ \\
\hline & Thyene semiargentea (Simon, 1884) & 1 & LC & $\mathrm{AE}$ \\
\hline & Thyene thyenioides (Lessert, 1925) & 1 & LC & $\mathrm{AE}$ \\
\hline & Thyenula fidelis Wesołowska \& Haddad, 2009 & 2 & LC & STHE \\
\hline & Thyenula oranjensis Wesołowska, 2001 & 3 & LC & SAE \\
\hline & Thyenula sempiterna Wesołowska, 2000 & 2 & LC & STHE \\
\hline & Tomomingi szutsi Wesołowska \& Haddad, 2013 & 4 & DD & SAE \\
\hline & Tusitala barbata Peckham \& Peckham, 1902 & 1 & LC & $A E$ \\
\hline
\end{tabular}


TABLE 1-A1 (Continues...): Checklist of the spiders of Blouberg showing endemicity value (EV), conservation status (CS) and distribution (Dist).

\begin{tabular}{|c|c|c|c|c|}
\hline Family & Species & EV & CS & Dist \\
\hline \multirow[t]{5}{*}{ Scytodidae } & Scytodes caffra Purcell, 1904 & 1 & LC & $A E$ \\
\hline & Scytodes clavata Benoit, 1965 & 1 & LC & $A E$ \\
\hline & Scytodes maritima Lawrence, 1938 & 3 & LC & SAE \\
\hline & Scytodes quinqua Lawrence, 1927 & 2 & LC & STHE \\
\hline & Scytodes thoracica (Latreille, 1802) & 0 & LC & $\mathrm{C}$ \\
\hline \multirow[t]{2}{*}{ Segestriidae } & Ariadna bilineata Purcell, 1904 & 3 & LC & SAE \\
\hline & Ariadna sp. 2 (new) & NE & - & - \\
\hline \multirow[t]{6}{*}{ Selenopidae } & Anyphops barbertonensis (Lawrence, 1940) & 1 & LC & $A E$ \\
\hline & Anyphops leleupi Benoit, 1972 & 4 & LC & SAE \\
\hline & Anyphops lochiel Corronca, 2000 & 4 & DD & SAE \\
\hline & Selenops brachycephalus Lawrence, 1940 & 2 & LC & STHE \\
\hline & Selenops lesnei Lessert, 1936 & 1 & LC & $\mathrm{AE}$ \\
\hline & Selenops tenebrosus Lawrence, 1940 & 2 & LC & STHE \\
\hline Sicariidae & Hexophthalma hahni (Karsch, 1878) & 2 & LC & STHE \\
\hline \multirow[t]{6}{*}{ Sparassidae } & Eusparassus jaegeri Moradmand, 2013 & 2 & LC & STHE \\
\hline & Olios chubbi Lessert, 1923 & 2 & LC & STHE \\
\hline & Olios correvoni nigrifrons Lawrence, 1928 & 1 & LC & $\mathrm{AE}$ \\
\hline & Olios freyi Lessert, 1929 & 1 & LC & $\mathrm{AE}$ \\
\hline & Olios sp. 3 (undetermined) & $\mathrm{NE}$ & - & - \\
\hline & Pseudomicrommata longipes (Bösenberg \& Lenz, 1895) & 1 & LC & $\mathrm{AE}$ \\
\hline \multirow[t]{3}{*}{ Tetragnathidae } & Leucauge levanderi (Kulczynski, 1901) & 1 & LC & $\mathrm{AE}$ \\
\hline & Meta meruensis Tullgren, 1910 & 1 & LC & $\mathrm{AE}$ \\
\hline & Tetragnatha boydi O.P.-Cambridge, 1898 & 0 & LC & $\mathrm{C}$ \\
\hline \multirow[t]{2}{*}{ Theraphosidae } & Ceratogyrus darlingi Pocock, 1897 & 2 & LC & STHE \\
\hline & Harpactirella overdijki Gallon, 2010 & 3 & LC & SAE \\
\hline \multirow[t]{21}{*}{ Theridiidae } & Anelosimus nelsoni Agnarsson, 2006 & 3 & LC & SAE \\
\hline & Archaearanea sp. 1 (undetermined) & $\mathrm{NE}$ & - & - \\
\hline & Argyrodes zonatus (Walckenaer, 1842) & 1 & LC & $\mathrm{AE}$ \\
\hline & Coscinida tibialis Simon, 1898 & 0 & C & - \\
\hline & Episinus bilineatus Simon, 1894 & 2 & LC & STHE \\
\hline & Episinus sp. 1 (new) & $\mathrm{NE}$ & - & - \\
\hline & Euryopis episinoides (Walckenaer, 1847) & 0 & LC & $\mathrm{C}$ \\
\hline & Euryopis funebris (Hentz, 1850) & 0 & LC & $\mathrm{C}$ \\
\hline & Latrodectus geometricus C.L. Koch, 1841 & 0 & LC & C \\
\hline & Latrodectus renivulvatus Dahl, 1902 & 1 & LC & $\mathrm{AE}$ \\
\hline & Phoroncidia eburnea (Simon, 1885) & 3 & LC & SAE \\
\hline & Phycosoma martinae (Roberts, 1983) & 0 & LC & C \\
\hline & Phycosoma sp. 1 (undetermined) & NE & - & - \\
\hline & Rhomphaea nasica (Simon, 1873) & 0 & LC & C \\
\hline & Steatoda capensis Hann, 1990 & 0 & LC & C \\
\hline & Theridion piliphilum Strand, 1907 & 3 & LC & SAE \\
\hline & Theridion purcelli O.P.-Cambridge, 1904 & 3 & LC & SAE \\
\hline & Theridion sp. 3 (undetermined) & NE & - & - \\
\hline & Thwaitesia sp. 1 (undetermined) & $\mathrm{NE}$ & - & - \\
\hline & Thymoites sp. 1 (undetermined) & $\mathrm{NE}$ & - & - \\
\hline & Tidarren cuneolatum (Tullgren, 1910) & 1 & LC & $\mathrm{AE}$ \\
\hline \multirow[t]{11}{*}{ Thomisidae } & Ansiae tuckeri (Lessert, 1919) & 1 & LC & $\mathrm{AE}$ \\
\hline & Diaea puncta Karsch, 1884 & 1 & LC & $\mathrm{AE}$ \\
\hline & Heriaeus peterwebbi Van Niekerk \& Dippenaar-Schoeman, 2013 & 2 & LC & STHE \\
\hline & Misumenops rubrodecoratus Millot, 1941 & 1 & LC & $A E$ \\
\hline & Monaeses austrinus Simon, 1910 & 1 & LC & $\mathrm{AE}$ \\
\hline & Mystaria savannensis Lewis \& Dippenaar-Schoeman, 2014 & 1 & LC & $\mathrm{AE}$ \\
\hline & Oxytate argenteooculata (Simon, 1886) & 1 & LC & $\mathrm{AE}$ \\
\hline & Ozyptila caenosa Jézéquel, 1966 & 1 & LC & $\mathrm{AE}$ \\
\hline & Parasmodix quadrituberculata Jézéquel, 1966 & 1 & LC & $\mathrm{AE}$ \\
\hline & Pherecydes lucinae Dippenaar-Schoeman, 1980 & 3 & LC & SAE \\
\hline & Runcinia flavida Simon, 1881 & 0 & LC & $\mathrm{C}$ \\
\hline
\end{tabular}


TABLE 1-A1 (Continues...): Checklist of the spiders of Blouberg showing endemicity value (EV), conservation status (CS) and distribution (Dist).

\begin{tabular}{|c|c|c|c|c|}
\hline Family & Species & EV & CS & Dist \\
\hline & Smodicinus coroniger Simon, 1895 & 1 & LC & AE \\
\hline & Stiphropus bisigillatus Lawrence, 1952 & 2 & LC & STHE \\
\hline & Synema decens (Karsch, 1878) & 2 & LC & STHE \\
\hline & Synema imitator (Pavesi, 1883) & 1 & LC & $\mathrm{AE}$ \\
\hline & Synema langheldi Dahl, 1907 & 1 & LC & AE \\
\hline & Thomisops pupa Karsch, 1879 & 1 & LC & AE \\
\hline & Thomisus australis Comellini, 1957 & 1 & LC & AE \\
\hline & Thomisus citrinellus Simon, 1875 & 0 & LC & C \\
\hline & Thomisus congoensis Comellini, 1957 & 1 & LC & AE \\
\hline & Thomisus daradioides Simon, 1890 & 0 & LC & c \\
\hline & Thomisus granulatus Karsch, 1880 & 1 & LC & AE \\
\hline & Thomisus kalaharinus Lawrence, 1936 & 1 & LC & AE \\
\hline & Thomisus machadoi Comellini, 1959 & 1 & LC & AE \\
\hline & Thomisus scrupeus (Simon, 1886) & 1 & LC & AE \\
\hline & Tmarus cameliformis Millot, 1942 & 1 & LC & $\mathrm{AE}$ \\
\hline & Tmarus comellinii Garcia-Neto, 1989 & 1 & LC & $\mathrm{AE}$ \\
\hline & Tmarus planetarius Simon, 1903 & 1 & LC & $\mathrm{AE}$ \\
\hline & Xysticus natalensis Lawrence, 1938 & 2 & LC & STHE \\
\hline \multirow[t]{6}{*}{ Trachelidae } & Afroceto martini (Simon, 1897) & 2 & LC & STHE \\
\hline & Fuchiba aquilonia Haddad \& Lyle, 2008 & 2 & LC & STHE \\
\hline & Jocquestus schenkeli (Lessert, 1923) & 1 & LC & $\mathrm{AE}$ \\
\hline & Orthobula radiata Simon, 1897 & 1 & LC & AE \\
\hline & Thysanina serica Simon, 1910 & 2 & LC & STHE \\
\hline & Thysanina transversa Lyle \& Haddad, 2006 & 3 & LC & SAE \\
\hline Trochanteriidae & Platyoides walteri (Karsch, 1886) & 1 & LC & $\mathrm{AE}$ \\
\hline \multirow[t]{3}{*}{ Uloboridae } & Hyptiotes ackermani Wiehle, 1964 & 3 & LC & SAE \\
\hline & Miagrammopes brevicaudus O.P.-Cambridge, 1882 & 2 & LC & STHE \\
\hline & Philoponella angolensis (Lessert, 1933) & 1 & LC & $\mathrm{AE}$ \\
\hline \multirow[t]{15}{*}{ Zodariidae } & Ballomma neethlingi Jocqué \& Henrard, 2015 & 5 & DD & SAE-LE \\
\hline & Caesetius inflatus Jocqué, 1991 & 1 & LC & $\mathrm{AE}$ \\
\hline & Capheris crassimana (Simon, 1887) & 2 & LC & STHE \\
\hline & Capheris decorata Simon, 1904 & 1 & LC & $\mathrm{AE}$ \\
\hline & Chariobos cylindriceus Simon, 1893 & 1 & LC & $\mathrm{AE}$ \\
\hline & Cydrela schoemanae Jocqué, 1991 & 3 & LC & SAE \\
\hline & Cydrela spinifrons Hewitt, 1915 & 3 & DD & SAE \\
\hline & Diores auricula Tucker, 1920 & 2 & LC & STHE \\
\hline & Diores lesserti Lawrence, 1952 & 3 & LC & STHE \\
\hline & Diores magicus Jocqué \& Dippenaar-Schoeman, 1992 & 2 & LC & STHE \\
\hline & Diores recurvatus Jocqué, 1990 & 2 & LC & STHE \\
\hline & Heradida bicincta Simon, 1910 & 2 & LC & STHE \\
\hline & Ranops caprivi Jocqué, 1991 & 2 & LC & STHE \\
\hline & Ranops sp. 1 (new) & $\mathrm{NE}$ & - & - \\
\hline & Systenoplacis fagei (Lawrence, 1936) & 3 & LC & SAE \\
\hline
\end{tabular}

Note: Endemicity: six endemicity categories, ranging from: 6 = endemic-known only from type locality/one locality only; 5 = known from one province only (SAE-LE); 4 = known from two adjoining provinces only; 3 = South Africa endemic SAE > 2 provinces or not adjoining; 2 = southern Africa (STHE); 1 = Afrotropical Region (AE); $0=$ Africa and beyond (C).

NE, Not Evaluated; DD, Data Deficient; LC, Least Concern; VU, Vulnerable; AE, Afrotropical Region Endemics; SAE-LE, South African endemic known from the Limpopo province; SAE, Southern Africa Endemics; STHE, Southern Africa Endemics south of Zambezi and Kunene Rivers; CS, conservation status; EV, endemicity value; Dist., distribution. 